\title{
Assessment and Mapping of Mudflow Hazard and Mudflow Risk in the Territory of Almaty
}

\author{
Akhmetkal Medeu, Viktor Blagoveshchensky, Tamara Gulyayeva, Sandugash Ranova \\ Institute of Geography and Water Security, Almaty, Kazakhstan
}

doi: https://doi.org/10.21467/abstracts.93.3

\begin{abstract}
A B S T RA C T
The Almaty city, located at the foot of the Zailiyskiy Alatau ridge, is the largest metropolis of Kazakhstan with a population of about 2 million people. The city is located on mudflow fans and has repeatedly been exposed to the destructive effects of mudflows. Mudflow disasters with big material damage and human casualties occurred in 1921, 1950, 1956, 1973 and 1977. Mudflows with material damage were recorded also in 1999, 2006, 2013 and 2019. Maps of mudflow hazard and mudflow risk are necessary for the development of measures for protection against mudflows. In 2018-2019 such maps were compiled by the Institute of Geography for Almaty on the instructions of the Department of Emergency Situations of Almaty. Maps were compiled at a scale of 1:25 000 using GIS technology. To compile the maps, archival data on mudflows from 1900, satellite images, and ground-based observations were used.

The mudflow hazard maps show the boundaries of mudflows of various volumes and repeatability. By volume, mudflows are divided into 4 categories: small $\left(<10\right.$ thousand $\left.\mathrm{m}^{3}\right)$, medium $\left(10-100\right.$ thousand $\left.\mathrm{m}^{3}\right)$, large (100-1000 thousand $\left.\mathrm{m}^{3}\right)$ and very large $\left(>1\right.$ million $\left.\mathrm{m}^{3}\right)$. In terms of repeatability: frequent mudflows (more than 1 time in 50 years), rare (1 time in 50-100 years) and very rare (less than 1 time in 100 years). The volume of mudflow in the field was determined by the maximum size of the boulders, and the frequency of occurrence was determined by the state of vegetation on the mudflow deposits. Long-term observations of mudflows in Zailiyskiy Alatau showed that boulders larger than $3 \mathrm{~m}$ can be brought only by very large mudflows, the volume of which exceeds 1 million $\mathrm{m}^{3}$, and the discharge $-10,000 \mathrm{~m}^{3} / \mathrm{s}$. If among the sediments there are boulders of more than $1 \mathrm{~m}$, it means that there was a mudflow with a volume of more than 100 thousand $\mathrm{m}^{3}$ with the discharge of more than $1000 \mathrm{~m}^{3} / \mathrm{s}$. The presence of boulders of $0.5 \mathrm{~m}$ in size indicates that the volume of mudflow was more than 10 thousand $\mathrm{m}^{3}$, and the discharge was more than $100 \mathrm{~m}^{3} / \mathrm{s}$.

If the surface of the mudflow deposits is deprived of grassy vegetation, and there are no lichens on the mudflow boulders, then the age of the mudflow deposits is less than 20 years. The presence of grassy vegetation, sparse shrubs and low trees, the appearance on the boulders of individual lichens shows that the mudflow passed about 50 years ago. Soddy cover, mature trees and large lichens on boulders are an indicator of the rare occurrence of mudflows. Mudflow cones with a dense adult forest, well-developed turf cover and numbing boulders are affected by mudflows less than 1 time in 100 years. The mudflow hazard maps also show large mudflow channels, dangerous moraine lakes, mudflow protection facilities, objects exposed to mudflows and mudflow destination time from the source to these objects. GIS layer with mudflow hazardous objects is interactive. It is associated with a database of objects exposed to mudflows, which provides information on the type of objects. its location, cost, social significance, exposure to mudflows and safety. All objects were divided into three categories: social, economical and environmental. Social objects include residential buildings, hospitals, schools, shops. Economical objects include enterprises, infrastructure elements. Ecological objects include specially protected natural territories and forests.
\end{abstract}

(C) 2020 Copyright held by the author(s). Published by AIJR Publisher in "Abstracts of The Second Eurasian RISK-2020 Conference and Symposium" April 12- 19, 2020, Tbilisi, Georgia. Jointly organized by AMIR Technical Services LLC, Georgian Technical University, Institute of Geography (Kazakhstan) and Russian Institute of Petroleum Geology and Geophysics.

DOI: $10.21467 /$ abstracts.93 
The Second Eurasian RISK-2020 Conference and Symposium

By cost, objects were divided into objects of low cost (less than 10 million tenge), average cost (10-100 million tenge), high (100-1000 million tenge) and very high cost (more than 1000 million tenge). The exposure of the object to mudflows was expressed by the frequency of mudflows of different volumes hit this object. The safety of objects was determined by the consequences of mudflows. If the object was destroyed completely or by more than $75 \%$, the safety was determined to be low. When the object was destroyed at 50-75\%, the safety was recognized as insufficient. When the object is destroyed by $10-25 \%$, the safety is good. With damage not more than $10 \%$ - high safety. The mudflow risk maps show territories with different levels of social, economical and environmental risks. Social risk was defined as the average annual number of dead and injured people. Economical risk was defined as the average annual economic loss. It was calculated based on data on the cost of objects, exposure to mudflows and the object safety.

Three levels of risk are identified: low, moderate and high. The risk level was determined by the severity of the emergency caused by the mudflow and the frequency of occurrence of such a situation. To determine the severity, the classification of emergency situations used in the Committee on Emergency Situations of the Republic of Kazakhstan was used. Emergencies in terms of the number of dead and injured and the size of property damage are divided into local, regional, interregional and global. By repeatability, emergency situations are divided into very frequent (usually 1 time in 20 years), frequent (1 time in 20-50 years), rare (1 time in 50-100 years) and very rare (less than 1 time in 100 years). The very rare recurrence of local emergencies corresponds to a low level of mudflow risk. The rare recurrence of local emergencies can be considered a moderate risk. The frequent recurrence of regional emergencies is already a high risk.

With a low level of risk, mudflow protection is not required. In territories with a low level of mudflow risk, it is quite enough land use regularity, have mudflow hazard maps and not place objects in mudflow hazardous areas. At moderate risk, land use regulation is mandatory, as well as the installation of an automated monitoring system and early warning of mudflows. With a high level of risk, in addition to all the above measures, the construction of protective structures and the preventive emptying of dangerous lakes are necessary.

On the territory of the Almaty city, high mudflow risk is noted in the Ulken river valley above the mudflow protection dam, where many cafes and restaurants were built in the 1990s, as well as on the Aksai river fan, where several villages with a total population of more than 30 thousand people are located.

Currently, preventive emptying is being carried out on dangerous lakes in the Kishi Almaty, Ulken Almaty, Kargaly and Aksay river basins. For this, pumps and siphons are used, as well as the laying of an open evacuation channel. In 2019, on the Kargaly lake, the water level was reduced by $3.7 \mathrm{~m}$, and the water volume was reduced from 78 to 35 thousand $\mathrm{m}^{3}$. As a result, when an underground breakthrough of the lake occurred on August 14, only a water flood passed along the Kargaly river. In 2015, during an uncontrolled breakthrough of this lake, a mudflow of 150 thousand $\mathrm{m}^{3}$ and a discharge of over $100 \mathrm{~m}^{3} / \mathrm{s}$ was formed. In 2019, the installation of a network of automated monitoring of mudflow hazard on the rivers Kishi Almaty, Ulken Almaty, Kargaly and Aksay was launched. Work will be completed in 2020. In the future, automated monitoring of mudflow hazard will be deployed in all mudflow hazardous valleys of Zailiyskiy Alatau. I addition two mudflow protection dams will be built in the Ulken Almaty and Aksay valleys. 